\title{
Festival Drama in the Blocks
}

\author{
Paddy O'Dowd \\ H Block 4, Long Kesh
}

As part of Féile an Phobail (the West Belfast Community Festival), republican prisoners in Long Kesh recently staged a performance of their play The Crime of Castlereagh an adaption of the Bobby Sands' epic trilogy of poems, 'The Crime of Castlereagh,' 'Diplock Court,' and 'H Block Torture Mill.' It charts the experiences of a prisoner as he moves from the physical and psychological torture of Castlereagh, to the farce of a Diplock trial, to the mixture of brutality and comradeship during the blanket/no-wash protest in the H Blocks.

This production had been nine months in the making. The previous week, the cast had spent many hours rehearsing and preparing. The capacity audience, which had packed the canteen, was full of expectations. At the end of the night, no one was disappointed. Indeed, what took place over the next hour-and-a-half far exceeded anything that might have been expected. This production was excellent and must be the most thought-provoking, emotionally-charged, and energetic play ever performed in the H Blocks.

The first scene wasted no time in setting the standard for the rest of the night. The curtains opened to reveal an iron bed from beneath which emerged two black-clad ghouls in grotesque masks, filling the state with an evil mischief. There was no room for idle props in this production, with the two figures using a towel as a noose, creating a mock gallows from the bedstead, and staging a mock hanging with both, all the while laughing menacingly.

The arrival of the prisoner (Frankie Quinn who brought great energy to a very demanding role) was swift and brutal as he was thrown onto the stage and ably assaulted by the guard or 'Watcher' (Tony Doherty who performed all his roles with a zeal). With the Watcher's departure, it soon became clear that the ghouls were the torments of the prisoner, all his fears and doubts come to life. Amid all their taunting, his loneliness and terror came across clearly, evoking a sympathy that was almost choking when the narration began:

I scratched my name but not for fame

Upon the whitened wall.

Micheál Mac Giolla Ghunna's delivery was perfect, the slow drawl carrying the feel of history and, as he was hidden from the audience's view, the walls themselves seemed to speak the words. And what better narrator of this trilogy than the walls of a $\mathrm{H}$ Block.

Bobby Sands was here, I wrote with fear In awful shaky scrawl. 
The audience had no difficulty in relating to the plight of the tormented figure on stage. The tension was razor sharp, built up with the music and sound effects of Eddie Higgins and Paddy Devenny using everything from bodhrán and whistle to kitchen utensils. Many a hair stood on not a few necks as the narration continued:

When Christ I stared as at me glared

The death name of Maguire.

'Maguire ... Maguire,' the ghouls echoed hauntingly (Brian Maguire died under controversial circumstances in a Castlereagh cell in May 1978).

After exploring the psychological torment of waiting for the interrogation, the scene shifted to physical pain. A casual costume change on stage (subtle but effective) transformed the ghouls into two interrogators. Dan Kelly and Mairtin og Meehan managed all the 'qualities' of these roles, even instilling a little humour amid the tense proceedings. Meanwhile, Johnny McCann and Marty Morris, as torturers' assistants, graphically demonstrated some of the ways they use:

To loosen up your tongue ...

Till a man cries for the womb

That give him birth to this cruel earth

And torture of that room.

The use of the sparse props throughout was superbly imaginative to which description on paper could never do service. Within this one scene, a pole was used in all manners from a torture rack to a stairway and none of it seemed out of place. To the strains of 'The Blanket Song,' the prisoner climbed to the top of that stairway, signalling his defiance in the face of the interrogators, and the end of the first scene. Thirty minutes had passed and no one was leaving their seats.

The second scene was set in a Diplock court. Its opening confronted us with the operatives: the doctor, who only diagnosed self inflicted wounds; the branchman and the prosecutor, all sharpening knives like butchers. The prisoner was dragged in by a screw, past this terrifying sight. Isolated, the prisoner was placed in:

That dock a lonely island there

And I a castaway,

The sea around alive with sharks

And hatred's livid spray.

In terms of imagery, this was unsurpassable: the re-enactment of torture, the physicalised murder of truth, the slithering snakes of witnesses, swooping 
prosecuting hawk, pig in wig judge, the circle of lies all done effortlessly and still with the ability to induce an emotional response from the audience. If the farce of Diplock and its central role in the conveyor belt system was ever 'captured,' this was it. The dignity of the prisoner was brought to the fore as he emerged from a repressive scrum of characters trying to bury him:

And see that splendid sun

That splendid sun of freedom born,

A freedom dearly won.

The audience was even more engrossed as the curtains closed a second time.

The opening of the third and final scene brought us to the ' $\mathrm{H}$ Block Torture Mill.' This conveyed the horrors of the blanket/no-wash protest, as well as the strength of those who endured the physical and psychological torture while tending others' wounds and pulling a comrade back from the edge of mental breakdown. Full credit to the cast for managing to put so much into one scene without it seeming disjointed or unreal. The sight of the three blanketmen lying in the background upstage while the death and funeral of the screw/torturer took place downstage was a striking image, one for the self-righteous politics of condemnation:

Yet! Whinging voices cried aloud,

What did this poor man do?

He only done what madmen done

Upon the silent Jew.

The part of the POW who is losing control in face of all the brutality was a great performance by Johnny McCann. Even the blankets around the men's bodies were used as props to signify the claustrophobic pressure whilst the selective use of sound effects cued us easily into the mounting degrees of tension. The pain of imprisonment was brought out by a fine piece in which, to the strains of 'Only Our Rivers Run Free,' one of the POWs escapes the squalor around him and dreams of a life beyond his concrete tomb:

To dance and prance to love's romance Is elegant and neat ...

But he is jolted back to terrible reality by his comrade's need to use the toilet which for him is the corner of the cell:

To eat and sit where you've just shit Is not so bloody sweet! 
The tension climaxed when the POWs were dragged out one at a time by the screws using various brutal search procedures. The cell was cleaned and the men were returned individually and badly assaulted, signifying all the horrors of the wing shift and the opportunism of the screws to systematically degrade and beat the prisoners. Yet the comradeship and unity of the blanketmen could not be broken:

And to our door we stood in scores

To conquer their black fame

For loud and high we sang our cry,

'A Nation Once Again.'

And while singing this song, the three POWs smeared the walls of their cell again. This was no romantic struggle, this was resistance by the only means available and a determination not to be defeated.

For the closing of the scene and the performance, the narrator emerged to walk among the cast reciting with conviction:

We do not wear the guilty stare

Of those who bear a crime.

Nor do we don a badge of wrong

To tramp the penal line.

So men endure this pit of sewer

For freedom of the mind.

The closing of the curtains ended an unforgettable performance, one greatly appreciated as shown by the sustained applause. This type of theatre had not been tried in the blocks before, and all involved carried it off superbly. Prisoners toughened and made cynical by long years of struggle were close to tears. With the lights turned on again, I sat in the brightness of the canteen amid the appreciative buzz of my comrades. The banner above the stage was so appropriate: 'Nor Meekly Serve My Time.' The words and imagery of Bobby Sands created under the most appalling circumstances have come a long way, from the darkest days of the blanket protest to the jail conditions that such sacrifice has achieved for us today, enabling his poetry to be brought to life by a new generation of republican prisoners. For those of us privileged to see it, this play was a proud reminder that we are part of that same noble struggle. 